\title{
MEDICAL MISSIONS IN YEMEN
}

It is nearly three thousand years since Homer said:-

"The man of medicine can in worth with many a warrior vie, Who knows no weapons to exercise and soothing salves supply."

I venture to assert that most mission workers in Moslem lands would hasten to fully approve the "Blind Bard's" way of phrasing a great truth. For most of the doors that have been open to the Gospel in Moslem countries and in Moslem homes have been unlocked through the medico's skill.

Certainly, in Arabia, no other servant of Christ has been more welcomed than the physician or the surgeon, though it may be that, like the deaf adder, the Arabs do, at first stop their ears to the Gospel and refuse to listen to the charmer, charming never so wisely.

Of course, the reason for physicians being welcomed is not far to seek, but I feel absolutely certain that even a display of the most wonderful skill would never have passed muster as a valid reason for the doctor's acceptance as an honored guest in a Moslem home had not Harith bin Kaldah, Mohammed's friend and trusted adviser, been a Christian physician. Up to the present day the strictest teachers of the Islamic code are bound to confess that the faithful may lawfully follow their great leader's example in consulting and carrying out the directions of a Christian doctor. The Caliph Mansur, in the heyday of Moslem vigor, was both treated and cured of a serious disease by a Christian physician, who so earned the Caliph's gratitude that he not only gave him a present of three thousand dinars and three beautiful female Circassian slaves, but also made him principal of the newly founded medical school at Bagdad.

It is, however, more than likely that the latter honor would never have been conferred on him had not his high 
moral tone and strictly Christian character appealed to the Caliph's sense of fitness. I believe that it was not until Georgius Bakhtishua had returned the three beautiful slaves, saying that it was not lawful for Christians to have more than one wife, that the Caliph selected him as the one man who was fit to be principal of his high medical school. At any rate the doctor continued to hold that high office until old age and sickness overtook him. For more than three hundred years the Bakhtishua family retained their religion, and continued to teach in the Medical College, as well as to be the most renowned pnysicians in Bagdad.

Other causes at work in South A rabia have also helped a medical man among Moslems. Just about the time of the Hejira there was a large and flourishing school of medicine in Sanaa, the capital of the Yemen, and as it is generally supposed that the principal of that school not only studied in India, but was himself a Christian, one can understand how it is that in Somaliland surgical operations that would never be attempted in any other Moslem country are still performed by the natives. Crosses are also found at the head and foot of many old graves, showing that, though excluded from South Arabia on account of their faith, yet these old Yemenites gloried in the Cross of Christ. They continued to glory in it until "the sons of God saw that the daughters of men were fair," and the mixed marriage did what persecution could not effect.

It would scarcely be honest, however, if one did not acknowledge the great debt, which the medical profession as a whole, and medical missionaries in particular, indirectly owe to Bishop Nestorius. It was wholly due to the persecution which arose out of the Nestorian heresy that very many clever and good men turned their attention to medicine, and there can be no doubt about it that the Landispur school would never have had an existence had not the Nestorians been forced to flee from Odessa, and to rarry with them into their new home that spirit of research and of independence which could no longer find 
a place of rest in a nominally Christian land. All know that it was at Landispur that a license to practice medicine was first granted, and those parchments given which differentiated the regular practitioner from the quacks and mountebanks, who were even more plentiful in those days than they are now. Moreover it was the teachers of this school who first showed the difference between pharmaceutics and therapeutics, thus clearing the way for a more scientific search.

Still it must be confessed that, though those Christian physicians were chosen to be a light, a leaven and a salt to the world with which they came into contact, they did not rise to the high calling whereunto they had been called. And not until the 16 th and 17 th centuries do we find the Jesuit missionaries using medicine as an adjunct to their work. It is from them that we got our knowledge of cinchona, ipecacuanha and many other drugs.

The igth century had dawned, however, before Protestant missionary workers thought of medical skill being employed. Then Dr. John Thomas was sent out to help Carey; Krishna Pal, the village carpenter, was brought into Christ's Kingdom through the medical man's instrumentality, and the holy fire began to spread in Bengal, which no human means could ever put out.

In the year 1822 , the need for medical missionary work was urged by Doctor Douglas of Cavers. In I 840 Dr. David Livingstone was sent out to Africa, and ever since the medical missionary's skill has been used in difficult fields, for it became increasingly plain that he could go and be welcomed where any other would only meet opposition.

Ion Keith Falconer knew this, and planned his mission in South Arabia on medical lines, as it became increasingly plain that necessity would draw even bigoted Moslems to the doctor, to whom many opportunities of speaking a good word for Jesus would be given, that would be denied to other earnest evangelists. Events have justified Keith Falconer's plan of action, as a visit to the doctor's 
morning clinique in any one of the Arabian mission stations will show.

The present doctor in Sheikh Othman is working alone, and therefore can see only a limited number of patients. He hopes, however, that when the hospital is fully equipped with nurses, and things come back to their prewar condition, huge crowds will once more be treated in the hospital, and on their sick beds will hear the story of the great Physician's power to heal both mind and body by purifying the soul.

Every morning at 7:30 o'clock there is an audience numbering from roo to 200 gathered together to hear the Gospel story before the morning clinique. On the preacher's left there may be 40 or 50 women and young children who have come for treatment. These, hidden from the male congregation, hear the wonderful woids of Life, and it will always be a pleasure to think that the first convert led to Christ by the writer in Arabia, like St. Paul's first convert in Europe, was a woman.

Many in the audience come long distances, some more than a thousand miles, carrying letters with them from old patients who have been healed in the hospital, telling of their welfare, and praying for a blessing on the mission. One who had been healed in body and cleansed in soul sent a donation of Rs 300 (nearly $\$ 100$ ) when he heard how the Turks had destroyed the hospital, and he prayed that others also might be brought into the light in the house of healing.

After the preaching service is over, the Rev. James Robson, who has now joined the mission, goes among the people and sells Scripture portions, which are carried far into the interior. We pray and believe that the entrance of God's Word will give light, and that Arabia will ultimately be won for Jesus Christ.

Aden, Arabia.

John C. Young. 